\title{
RESPONSE
}

\section{A Few Words on the Last Words of Condemned Prisoners Robert Johnson}

\begin{abstract}
T ast words are the existential centerpiece of executions. The prisoner, by his last words, gives meaning to the execution as the culmination of his life (see Johnson et al., 2013). His life has come to this place, the death house, a remarkable fact about which remarks are warranted. Whether eloquent or inarticulate, terse or rambling, the prisoner's last words are the last word about his life. Even saying nothing is saying something in this context, communicating that the person at this fateful juncture of his life is rendered speechless by the enormity of the violence that awaits him, made mute by the unspeakable cruelty of the killing process.

I do not use the words enormity and unspeakable here without cause. In the execution chamber, a healthy person, often young and fully under the control of the authorities, is put to death by an execution team that works from a rigid script, captive to rote, unfeeling procedure (see Johnson, 1998). The execution team performs in front of an audience of people - for the most part, official witnesses and correctional officials -who look on and do nothing, say nothing. They watch the prisoner die, then file out and go home, carrying the scent of the death house with them out into the free world. That scent, which my field research on the execution process led me to describe in a poem as "a / devil's brew of / mildew, flesh, and / fear", has a way of lingering in the sense memories of those touched by executions (Johnson, 2010, p. 140). Poetic justice, perhaps, courtesy of the death house.
\end{abstract}

\section{MODERN EXECUTION RITUAL}

Modern executions follow a macabre process that includes several rituals (see Johnson, 1998). One ritual is the last meal. There is a haunting element of abandonment at work during the last meal, an ostensibly charitable undertaking that offers the prisoner a moment of autonomy - he can choose his meal, even ordering a steak if one can be found in the prison kitchen, and he can eat the meal or not eat it, even share it with the death watch guards if he is so inclined (see, for example, Johnson, 1998; Meyer, 2011). As a general matter, the condemned prisoner eats alone, even though there are others at the table or in the room or just outside the cell, depending on the logistics of last meals, 
which varies from prison to prison (Johnson, 2003). The bottom line is this: the condemned man eats, others watch, no one lifts a finger to help this fellow human being within arm's reach, clearly in need, on display like an animal in a zoo, if one can imagine a zoo that feeds and then kills its inhabitants.

In a poem called "The Last Supper", undertaken as an exercise in ethnography, I described the hollow, chilling experience of observing a last meal. The man ate his last meal alone in the death house, watched from the area immediately beyond the bars of his cell. Some observers, notably prison officers, were a mere foot or two away from him, me a few feet farther back, observing the officers and others observe the prisoner, and also observing the prisoner as he ate his last meal. Here is what I saw, and felt, and learned from my observations, written in the present tense to best capture the scene:

A fried steak, diced into little squares,

arrives at the death house

neatly reassembled, like a puzzle,

laid to rest in the center berth

of a standard white Styrofoam box

bordered on one side by soggy, sagging fries,

on the other by wilted greens, curled and brown,

long past their salad days, like the man himself

who ordered this meal as the sad celebration,

culmination, of a dreary, wasted life

that it is even now slipping away

as he ages before our eyes right there in his cell,

called "the last night cell" in some prisons,

"the death cell" in this one...

He eats alone with a plastic fork -

no knives for the condemned,

no dinner companions for the condemned -

chewing carefully, kneeling by his bed, as if in

genuflection before the raw power of the state,

his meager meal placed carefully on the steel gray metal bed,

sitting precariously on the top sheet, drawn tight

like a sail battened down for heavy weather. 
We look at each other tentatively, almost furtively, lawyers, chaplains, even officers speaking in low tones, words directed toward the ground, as if we are greasy, dirty, our mouths dry, tongues swollen, sticking to our teeth,

$-$

our noses stinging from the scent of corruption, the bittersweet stink of fear in the air, in our hair, on our skin, in our clothes.

We are guests at a living wake, where the dead live, where the dead see, look you in the eye and see nothing, see no one will save them see they are utterly alone.

The condemned man finishes his meal, says 'thank you' to the officers who fed him dinner, and later walks with them to his execution, on schedule, dead before the stroke of midnight. We go home, stomachs empty, hungry for sleep.

- "The Last Supper” (Johnson, 2010, pp. 148-149)

It is remarkable, at first blush, that a condemned prisoner would say "thank you" for his last meal. But many do, because even a crumb of kindness feeds a hunger in the human heart for compassion, even the appearance of compassion. Sometimes the words "thank you" are the sum and substance of the last words of the condemned, spoken with feeling and meant to include family and friends. However, dysfunctional these relationships may have been in the world, they are valued in the death house for the glimmers of hope and affection and loyalty they embody. Thanks are extended to the execution team members as well, both behind the scenes and in formal last words; some officers are appreciated for the small civil gestures that soften the harsh protocol of the execution process: "Thank you. Thank you my last meal. Thank you all for ending this nightmare with a hint of human feeling, genuine or not, in an otherwise dehumanizing process that unfolds like clockwork against a backdrop of utter indifference". Loved ones are 
grateful for testimonials of love in the last words of the condemned. To my knowledge, no one in authority is grateful. No one in authority has ever said to the prisoner, "You are welcome". The reason is simple: condemned prisoners are not welcome in the death house. They are there to be killed, even if we are civil about it. A night in a death house with an execution team drives home this sad and sordid fact. The paradoxical quality of gratitude to staff in the death house leaves them speechless, so they say nothing, speaking volumes.

\section{MOMENTS OF HUMANITY}

Last meals and last words are moments of humanity in an otherwise inhumane ritual (see LaChance, 2007; Meyer, 2011). Last words, like last meals, offer a moment of autonomy on the threshold of death, allowing the prisoner to bring meaning to an execution that is otherwise out of his control. Research on the content of last words has unearthed several specific themes, notably love and gratitude for those family and friends who have stood by the prisoner until the end, and regret, sorrow, and guilt over the harms the offender has wrought (Meyer, 2011, p. 188). Last words are delivered as a kind of speech. The warden looks to the prisoner and asks, solemnly, "Do you have any last words?" Most condemned prisoners do, saying something like "Yes, I do", at the outset, and then starting, in the manner of all speeches in all contexts, by thanking those who have come to support them, often thanking God as well, offering up acknowledgements and statements of love and gratitude to man and deity that sometimes have the feeling of an Oscars ceremony speech, albeit a dark version of one. After this opening gambit, comments usually follow having to do with how the prisoners understand the fateful proceedings that are unfolding even as they speak, after which the speech ends with some variant of, "That's all I have to say". In Texas, home to more executions than any other state, the warden then gives the signal for the lethal chemicals to be released. The prisoner thus has, literally, the last word in the matter of his execution (LaChance, 2007).

In between opening thanks to loved ones and closing remarks, the gist of these last-words speeches is a statement by the prisoner about his understanding of what is happening to him and why, typically framed as a long goodbye and often rendered in a thoughtful, even philosophical way. The subtext is that this man before you is a decent human being whose life 
is worth something, certainly worth remembering. Here is an example of last words, given by a man named Ronald C. O'Bryan, which illustrates many of the themes we have discussed:

What is about to transpire in a few moments is wrong! However, we as human beings do make mistakes and errors. This execution is one of those wrongs yet doesn't mean our whole system of justice is wrong.

Therefore, I would forgive all who have taken part in any way in my death. Also, to anyone I have offended in any way during my 39 years, I pray and ask your forgiveness, just as I forgive anyone who offended me in any way. And I pray and ask God's forgiveness for all of us respectively as human beings.

To my loved ones, I extend my undying love. To those close to me, know in your hearts I love you one and all. God bless you all and may God's best blessings be always yours.

Ronald C. O'Bryan

P.S. During my time here, I have been treated well by all T.D.C. personnel. -- Texas Department of Criminal Justice, Executed Offenders (2013)

O'Bryan's last words portray a man who is thoughtful, rational, even wise, as well as compassionate, forgiving, and loving. His execution is a miscarriage of justice, he claims, but not all executions are wrong or "mean our whole system of justice is wrong". To err is human, we learn; he, like us, is a human being and must live, or better, die in this imperfect world. In a spirit of reciprocity, he offers forgiveness to all implicated in his wrongful execution, just as he asks forgiveness from others for the wrongs he has committed against them, even if the crime at issue is not one of those wrongs. He asks God's forgiveness, including himself with all others under God's dominion "as human beings". He reassures his loved ones and wishes them well in the form of God's "best blessings". In closing, he reaches out to the staff members who have housed him on death row and are now about to carry out his execution: "I have been treated well by all T.D.C. personnel". O'Bryan's last words, like many if not most last words, "mix memory and desire in a last-ditch effort to transform 
a life that was a wasteland of loss and violence into a life worth having lived and, perhaps more importantly, a life worth remembering after the offender is gone" (Johnson et al., 2013, p. 24).

Occasionally, the dominant theme of last words is the persistence of rank injustice in life, expressed in angry finger-pointing. These last words tend to be disjointed, even rambling, lurching alone on waves of pitched emotion. The key element is shifting blame - to others, even sometimes to inanimate objects. Here is an example, from a man named Virgil Martinez:

Yes I do. Um Abel, Love ya'll, Evelyn love ya'll, Armando and Delia I love ya'll. Do what I told you and you will see me one day. Do that and promise me. First, Veronica's sister. I know what you've been told and that's all a lie. John Gomez killed your kids and sister. I know ya'll love John Gomez but he was a violent man. I wish I would have shot him in the leg, then he would be here. Those investigators were just trying to convict somebody. My gun had a hair trigger. Veronica told me to come and get my herb book and she went to the back of the closet. Her kids had asthma and I lent her the book. She said she would give it to me next time. She didn't want to break up, we still talked. She told me to come over. John Gomez said Veronica does not have the money for your book so don't come over. Me being a hot shot I went over there and I had my gun. I had children and nephews where I lived so I had to keep my gun in my truck for self-defense. Veronica invited me in her house, the kids were still awake fixing to go to bed. I put the gun under my shirt and said Hi to Josh and Cassandra. John Gomez was there he told Veronica that "he doesn't love you". I didn't care.

- Texas Department of Criminal Justice, Executed Offenders (2013)

There is a profession of love at the outset of Martinez's last words, but this sentiment is belied, or at least overshadowed by the overwhelming theme of shifting the blame to others - from the person who allegedly committed the crime, whom he should have shot "in the leg" on the scene, to the monomaniacal investigator in a rigged justice system, to the "hair trigger' gun he "had" to have for self-defence to protect his children, but which he carried with him into a contentious domestic situation that ended in a bloodbath of his doing, taking the lives of "a 27-year-old Hispanic female, her two children (a 3-year-old Hispanic female and a 6-year-old Hispanic 
male), and an 18-year-old Hispanic male". Martinez does not appear to be a man at peace with his crime, his life or his impending death. One imagines him expressing his resentments and minimizing his culpability on the day of his arrest, then nurturing hard feelings over his years on death row, and finally spewing them forth in the death house.

Many capital mitigation experts can identify a host of brutal injustices that help shape the lives and crimes of condemned prisoners (see Haney, 2005) and these factors may well apply to Mister Martinez. But to shape a life is not to determine it. Violence always boils down to a choice, a life-altering choice. A focus on injustice and the bitterness it breeds in one's last words does not serve as an effective means to transform a sordid life into one worth living or remembering. Instead, these negative, even nihilistic last words document the wasteland of the prisoner's life and wallow in it. Last words of anger and blame are no doubt offered in the hope that others will be persuaded to think better of the person - to see him more as victim than victimizer - but excuses always ring hollow, perhaps especially in the death house.

Given the arbitrariness of life, not to mention the legal system-especially in capital cases, a closed and arbitrary system unto itself (see Haney, 2005) - it is instructive that thoughtfulness and compassion typically trump resentment and anger in the death house. We all have grievances. At life's end, even in the death house, the more ennobling choice may be to take responsibility where one can, finding meaning and value in the way you played the cards you were dealt in life.

\section{DEATH HOUSE THEATRE}

Last words are, in the main, highly rehearsed speeches given under duress on the unusual stage presented by the death house, which serves as a kind of theatre for executions, much in the way a battlefield is a theatre of military operations. Imagine the context. One is about to be killed before several discrete audience groups, typically representing: 1) the victim, represented by a group of witnesses generally happy to see you die; 2) your family, often a dysfunctional group but one that nevertheless stands by you, even though they are hurt - by you and by the process you have dragged them into; and 3) official witnesses, who often feel preoccupied and out of place, a bit like voyeurs with a good cover. Official witnesses come late to a story of violence with deep and sometimes convoluted plot lines. They are largely 
oblivious to the human drama unfolding before them - they have been drafted at the eleventh hour into an impersonal process meant to convert the prisoner into an object of execution, a deadly and unredeemable criminal, not a person on the threshold of tragedy who has brought tragedy to others in turn (see Johnson, 1981; Johnson, 1998).

The death house, then, provides a forbidding stage: the audience is varied and, themselves under a range of emotional stresses given the momentous undertaking at hand, hard to engage. Knowing this, or at least sensing this, the prisoner often writes and revises and rehearses his last words in his cell, while he waits to see the death house chaplain. He imagines telling his life story, or at least its denouement, while strapped down to the main stage prop, a gurney on which he is restrained with catheters in his arms, struggling to be heard since the witnesses are off to each side, not easily seen; the supine prisoner can only see the ceiling, unless he cranes his neck left or right, fighting against the restraints. It is a wonder condemned prisoners are able to speak at all, so much is the pressure and so difficult is the task of summarizing a life on the edge of what must seem like an abyss, lethal drugs at the ready, a modern poison potion poised to strike like a chemical Damocles' Sword.

It is one thing, one must suppose, to summarize or remark upon a life that has gone well, cataloguing things and people in which one can take pride. Not so in the death house. Things have gone terribly wrong; lives have been taken, others ruined. The world the prisoner knew, and which knew him, is in tatters, an endless vista of trauma and loss. His suffering may end in the death house, but not so those he leaves behind. What does one say in this situation? Thank you, certainly; in this context, a vast understatement of the debt owed to loved ones. "I'm sorry" and "forgive me" rank high, as one would suppose, and as we saw in the sample last words of Mister O'Bryan, above. Variations on the theme that "I am not that person, that monster, anymore" make up the text or subtext of many, if not most, last words. A few make excuses and point fingers up to the bitter end, suggesting a life of recrimination that simmered and boiled during years on death row, burning away any compassion the prisoner might have felt for others or even for himself, whose deeds he simply cannot face and own. Some crimes, sad to say, are so awful they are incomprehensible, even to their authors. O'Bryan, for example, was sentenced to die for poisoning his young son on Halloween. Who could face that horror 
without the cover of a fallible justice system, one mercifully prone "to mistakes and errors"?

Executions are a dehumanizing business. Life on death row is a form of torture that blooms in solitary confinement (Johnson, 1981). After years, even decades of isolation, most condemned prisoners, overwhelmed by the force of the state and undermined by doubt and fear, go to their deaths compliantly, even meekly, "humble men" in the words of the execution team I studied (Johnson, 1998). But for many prisoners, last meals and especially last words offer brief but vital escapes from the crushing momentum of executions, little resurrections from the living death of death row and the death house (Johnson, 1981). There is a brief pause in the killing process, and that pause breaks the routine, giving people a fresh view of things, in this instance, a window for expression of profound changes in the self that have emerged from the crucible of life under sentence of death. Simply to survive as human beings, condemned prisoners must find meaning in their lives and in their suffering. They adapt, and in adapting, they change. Last words are meant to testify to that change. This is me now; this is who I am or strive to be, at least now, at least here. Before, I was someone else. Now, I am me; remember me for how I died, not how I lived.

Many, perhaps most condemned prisoners use their last words to affirm that they are indeed new men, better men, men who go to their deaths with some poise, even dignity. The execution process is dehumanizing; condemned prisoners, with their last words, transcend the killing routine and speak their minds. This dignity in adversity, hard won, sets them apart from others in the death house, those workers and witnesses and observers who wonder - I know from experience - if they have not shed some of their own dignity by the sheer and unforgiving fact of their participation in the execution process.

\section{REFERENCES}

Haney, Craig (2005) Death by Design: Capital Punishment as a Social Psychological System, New York, NY: Oxford University Press.

Johnson, Robert (2010) A Zoo Near You, Henniker (NH): BleakHouse Publishing.

Johnson, Robert (2003) "Life Under Sentence of Death: Historical and Contemporary Perspectives", in James R. Acker, Robert M. Bohm and Charles S. Lanier (eds.), America's Experiment With Capital Punishment: Reflections on the Past, Present, and Future of the Ultimate Penal Sanction, Durham (NC): Carolina Academic Press, pp. 647-671. 
Johnson, Robert (1998) Death Work: A Study of the Modern Execution Process (second edition), Belmont (CA): Wadsworth.

Johnson, Robert (1989) Condemned to Die: Life Under Sentence of Death, Long Grove (IL): Waveland.

Johnson, Robert (1981) Condemned to Die: Life Under Sentence of Death, Amsterdam, (ND): Elsevier.

Johnson, Robert, Sandra McGunigall-Smith and Claire Callahan (2013) "Can I Get a Witness? Thoughts on Viewing Executions", The Prison Journal, 93(1): 11-33.

LaChance, Daniel (2007) "Last Words, Last Meals, and Last Stands: Agency and Individuality in the Modern Execution Process", Law and Social Inquiry, 32(3): 701-724.

Meyer, Linda (2011) "The Meaning of Death: Last Words, Last meals", in Austin Sarat and Karl Shoemaker (eds.), Who Deserves to Die, Boston: University of Massachusetts Press, pp. 176-206.

Texas Department of Criminal Justice (2013) Executed Offenders. Retrieved from $<$ http://www.tdcj.state.tx.us/stat/dr_executed_offenders.html $>$.

\section{ABOUT THE AUTHOR}

Robert Johnson is a Professor of Justice, Law and Society at American University, as well as Editor and Publisher of BleakHouse Publishing. He is a widely published and award winning author of books and articles on crime and punishment, including works of social science, law, and fiction. He has testified or testified expert affidavits on capital and other criminal cases in many venues, including U.S. state and federal courts, the U.S. Congress, and the European Commission of Human Rights. He is best known for his book, Death Work: A Study of the Modern Execution Process, which won the Outstanding Book Award of the Academy of Criminal Justice Sciences. Johnson is a Distinguished Alumnus of the Nelson A. Rockefeller College of Public Affairs and Policy, University at Albany, State University of New York. 